Among other notable features of the meèting were a joint discussion, together with the zoologists, on the Cell; a public lecture on Fossil Plants by Mr. A. C. Seward, who, since the death of Williamson, has been recognized as the leading paleobotanist in Great Britain ; and joint action with the Sections of Zoology and Physiology for the establishment of a biological station in the Gulf of St. Lawrence. While it is intended that such a station shall be primarily designed for economic ends in connection with the fisheries, it is hoped that opportunities may be offered for a limited number of students to pursue special investigations relative to both animal and plant life, and thus to supplement the work of larger stations, such as that at Woods Holl.

The special interest of the Section centered in the presidential address, which dealt in a very masterly manner with the progress of botanical science during the latter half of the Victorian reign. The address was a very noteworthy one from several points of view, though chiefly as an important historical summary. While it would be difficult and altogether unsatisfactory to attempt an abstract of a paper so rich in facts, it may be pointed out that it gave the strongest evidence to show the great dependence of important commercial undertakings and economic processes upon data derived from modern scientific botany, as also the very close relations which exist between chemistry and botany as now known. The address will form a useful key to a much wider literature, and deserves the careful perusal of the specialist as well as the general morphologist.

D. P. P.

MARINE BIOLOGICAL LABORATORY.

A STATEMENT TO THE CORPORATION FROM THE TRUSTEES.

The annual meetings of the Corporation will hereafter be held at Woods Holl in
August instead of at Boston in November, and absent members can now vote by proxy. The Board of Trustees has been enlarged to twenty-seven members, and the new Board, it is believed, fairly represents nearly all sections of this country and Canada. The closer cooperation of all institutions of learning is actively encouraged.

These changes will make possible the attendance of a large number of members, at annual and special meetings, who have been unable to reach Boston during the month of November, and there are already signs of increasing interest in the institution over a much wider area. The members will be glad to learn that, at the recent meeting of the British Association in Toronto, Dr. Dohrn, head of the unrivalled station at Naples, took occasion to speak as from personal knowledge in terms of warm commendation of the work at Woods Holl. The past summer has been highly satisfactory; but the Trustees have been hampered by lack of funds for needed repairs and renewals, and, to some extent, for current expenses. At least $\$ 1,000$ should be raised before resuming work next summer, and there remains a debt of about $\$ 4,700$ incurred for the erection of new buildings. This debt should be cancelled in order that a clear balance sheet may be shown before undertaking several most desirable extensions of the plant, some of which are urgently needed. Salaries should be increased, and greater inducements offered to the strong corps of instructors and workers whose collaboration has enabled the institution to attain its present position in the scientific world. Moreover, there is no assurance of permanence in an institution of this nature until it shall have acquired a sufficient endowment or maintenance fund, independent of its land, buildings and equipment (which now represent an investment of over $\$ 33,000$ ), to relieve it from danger of extinction by one or more sea- 
sons of small attendance. The Endowment Fund now amounts to over $\$ 3,500$ and has been carefully husbanded, but it should be increased to at least $\$ 50,000$. And the special funds, the Lucretia Crocker Fund for Scholarships and the Library Fund, may profitably be added to.

One effect of the recent changes in the By-laws will be, or may be, to diminish the special interest in and sense of responsibility for the Laboratory heretofore shown in the city of Boston and its immediate vicinity, to which, as is well known, the institution owes its initial impulse and much continuous and generous support. In appealing, as they do now, to a wider constituency, the Trustees are in no wise unmindful of the debt which the cause of science and of sound learning owes to this intelligent and kindly support in the past, some of which support, as they are assured, will hereafter be extended, with unwearied generosity, from the same locality. The Laboratory now looks to the country at large for its main sources of income and upon all the corporate members, in whose hands the recent changes have placed the entire control, rests the correlative duty of supporting the work. With power comes responsibility.

The Trustees, therefore, have decided to raise the annual dues of members of the Corporation to two dollars $(\$ 2.00)$. The fiscal year now begins on the second Tuesday in August, and this sum is due for the year ending August ' 9 , 1898. Members of the Corporation will kindly forward it, together with all back dues, to the Treasurer, D. Blakeley Hoar, 220 Devonshire St., Boston, Mass.

For the reasons given above, the Trustees also appeal to the members of the Corporation to send with their annual dues such further sums, however small, as the means and interest of each in the work may inspire. All contributions will be duly noted in the annual report which is in course of preparation and will be issued early in the coming year. A contribution of not less than $\$ 100$ entitles the donor to a life membership, exempt from annual dues, or, at his option, to nominate a person to occupy a private room in the Laboratory, free of charge, during one season. A contribution of $\$ 50$ entitles the donor to a free scholarship, exempt from tuition fees, during one season. Contributions of smaller amounts will be gratefully received and duly acknowledged.

The forthcoming report will show fully all the recent changes in the organic law of the Association, and will be sent to all members in good standing.

By order of the Trustees,

Henry F. Osborn, President,

H. C. Bumpus, Secretary,

D. Blakeley Hoar, Treasurer,

C. O. Whitman, Director.

Edward G. Gardiner, Chairman of Executive Committee,

James I. Peck, Assistant Director, Executive Committee,

Camillus G. KIDDER, Executive Committee.

All matters relating to scientific administration should be addressed to Professor C. O. Whitman, University of Chicago, Chicago, Ill. All applications for membership, to the Secretary, Professor H. C. Bumpus, Brown University, Providence, R. I. All dues and subscriptions, to the Treasurer, D. Blakeley Hoar, 220 Devonshire St., Boston, Mass.

\section{A NEW LABORATORY DISH.}

IN the laboratory of the college we use for routine work the paraffin method almost exclusively. The blocks of tissue are infiltrated in the usual manner, and the sections cut with the Ryder or Minot microtome. The student cuts his sections and fastens them on to the slide by means of Ole- 